\title{
The Link Between Corporate Governance and Corporate Social Responsibility in Insurance
}

\author{
Lutgart Van den Berghe and Céline Louche \\ Vlerick Leuven Gent Management School, Gent, Belgium. \\ E-mail: celine.louche@vlerick.be
}

Based on the argument that corporate social responsibility is not just a fashion but rather the future from another angle, this paper explores the link between corporate governance and corporate social responsibility in insurance. Although insurance industries have been less exposed to criticisms than other sectors, like any other business, they are subject to increasing societal scrutiny. After a short reconsideration of the corporate governance paradigms and mechanisms, the paper analyses the relevance of corporate social responsibility and corporate governance for the insurance sector. It explores its positive and negative externalities and its role as institutional investor. The paper also provides policy recommendations for mainstreaming corporate social responsibility within the sector.

The Geneva Papers (2005) 30, 425-442. doi:10.1057/palgrave.gpp.2510034

Keywords: corporate governance; corporate social responsibility; insurance; externalities

\section{Introduction}

Corporate social responsibility: yet more hype without a sustainable future, or the future from another angle?

Time and time again, with the regularity of a clock, businessmen and management professors find themselves assailed by new business fashions, pretending to hold the absolute and definitive key to strategy and thus to the future of the company. Kenneth Clark pointed to the danger of this when he stated that "Confident articles on the future seem to me, intellectually, the most disreputable of all forms of public utterance". ${ }^{1}$ It would be understandable to certain readers of this article to reject the concept of corporate social responsibility (CSR) as being just another business fashion, a new religion or a new ideology, which in practice has nothing to offer; understandable, but wrong, at least in the opinion of this article's authors. ${ }^{2}$

The present contribution represents a reconnoitering of the future of business conduct and governance. To avoid provoking the above criticism of Kenneth Clark, however, we would just say that, in such an exercise, posing the right questions (and particularly continuing to pose them) is more important than giving answers, which

\footnotetext{
${ }^{1}$ Quoted in Barrow (1998).

${ }^{2}$ Van den Berghe and Verbeke (2001).
} 
will necessarily change anyway over the years. Indeed, anyone attempting to promote his or her piece of the truth as the entire truth destroys its value.

Becoming involved in CSR can be seen as a passionate expression of faith. While disclaiming a passionate involvement, we aim to analyse the contextual factors that could lead to CSR simply being a sensible strategic option in the chaotic world we live in, or at least in a number of industries closely connected with the knowledge society. Before doing so, we have to point to the link between CSR and corporate governance in the insurance sector.

\section{Approach and hypothesis of this contribution}

Faced with the increasing pressure for CSR and a broader role of business in society, it is no longer sufficient for a "responsible firm" to live by the law and focus on financial profit to create value for shareholders. This is also true for the financial and insurance sector. However, traditional corporate governance as well as traditional management tools and accounting principles do not allow CSR to be managed efficiently and effectively. This is the central thesis we want to discuss in this article.

The first section of the paper highlights the increasing focus on the role of business in society and its effects on corporate governance. The concept of CSR is closely allied to that of governance. Both CSR and corporate governance have to do with the direction of companies and with the translation of that into corporate strategy.

The second section addresses the relevance of CSR and corporate governance for the insurance sector. In this section, we investigate first the sector's positive and negative externalities, secondly its role as institutional investor and thirdly we suggest some policy recommendations in order to mainstream CSR and corporate governance within the insurance industry. The concluding section presents some reflections and ideas for further research.

\section{Increased focus on the role of business in society and its effects on corporate governance}

\section{Business conduct is under growing scrutiny and paradigms are changing}

Business conduct is under growing scrutiny. There is increasing focus on the role of "business in society" which shows a manifestation of change: business firms should have a "responsible" attitude and behaviour, wherever they operate. This goes to the heart of CSR, which presumes a conscious search for a balance, beyond short-term efficiency, in order to achieve long-term, sustainable success, based on a balanced respect for the interest of all parties involved in the company.

Corporate scandals like Enron or WorldCom in the United States, Ahold in the Netherlands, Vivendi in France or Parmalat in Italy also resulted in a growing criticism against business managers and directors. It reveals shortcomings of corporate governance. A more thorough analysis of these corporate failures, which goes beyond the search for the "guilty", clearly shows numerous failures of "business monitoring": 
market failures, internal monitors that failed, failed shareholder monitoring and also management failures. ${ }^{3}$

Paradigms are changing. Companies are facing a new invisible hand, ${ }^{4}$ that is, nonmarket forces exerted by NGOs, media, trade unions and others. This is a powerful force that reigns in the business world and definitely opened-up the black box of board and management trade-offs and decision-making. Stimulated and influenced by this new invisible hand, market parties also start to consider CSR and good corporate governance as the prerequisite for sustainable growth and welfare within a globalizing business environment.

Faced with the combined forces of the new invisible hand and the alerted market parties, the business world can no longer ignore its increased societal accountability as well as its externalities. ${ }^{5}$ Externalities are the side effects of corporate activities on society. They can be either positive (economies) or negative (diseconomies). In this respect, traditional corporate governance and management paradigms need a thorough reconsideration.

\section{The need for a new corporate governance paradigm and mechanisms}

The recent wave of corporate scandals in the United States (Enron, Worldcom, Tyco, etc.) and in Europe (Parmalat, Ahold, Vivendi, Lernout and Hauspie, etc.) has brought lots of attention to corporate governance.

Corporate governance has been defined by Sir Adrian Cadbury as the direction and control of the company. In philosophic terms, it has to do with transparency, with accountability (in the sense that our errors can be laid to our score) and with honesty. In methodological terms, it has to do with the necessity of achieving greater certainty in the correctness of decisions being taken and achieving that via a number of measures (structures, processes, checks and balances, correct monitoring, etc.). Proper governance will thus probably lead to the situation where, in a board of directors, various strands of interest (family shareholders, institutional investors, management and the common good) may and ought to be brought forward in discussion, but where ultimately resolutions have to be taken (by all) in the interest of the company, an interest that all members of that board are required to serve.

The idea of governance rapidly leads to questions that go beyond methodology and efficiency: what the purpose of business is, what the interest of the company is that has to be served, where the balance has to be sought between return and, for example, social responsibility. In this sense, corporate governance is a methodology for sustainability and a guard against the blinkered vision that can send a company down the wrong path. Furthermore, corporate governance and CSR are two concepts that draw vigour from the same sources: transparency, accountability and honesty.

Given the increased expectations towards business in society and taking into consideration the increasing mistrust caused by corporate failures, corporations need

\footnotetext{
${ }^{3}$ For more detail, see Van den Berghe and Baelden (2003).

${ }^{4}$ Huysse (1999).

${ }^{5}$ Van den Berghe and Carchon (2003).
} 
to move towards responsible corporate governance that can balance the legitimate interests of all stakeholders involved and emphasizes ethics and sustainable growth. Mainstream corporate governance, dominated by the traditional neo-classical view of the firm focusing on shareholders and financial performance, ${ }^{6}$ is being criticized. A number of underlying paradigms need to be redefined or questioned. First, there is a need to redefine the role of the firm from the perspective of business in society and thereby to integrate more modern theories of the firm and alternative theories such as the resource-based view, the knowledge-based view, the networkers and the communitarians view. ${ }^{7}$ Second, one of the big challenges for corporate governance theories is to shift from the traditional principal-agent theory to the management of complex principal-agent relationships to take the many stakeholders' interests into consideration. There is a need to integrate complex sets of relationships and their potential conflicts of interest and develop governance mechanisms to manage them effectively and efficiently. Third, the pure shareholder thinking as primary goal of corporations needs to be revised towards sustainable value creation. ${ }^{8}$ And finally, the question is whether there is a convergence to the dominant firm logic. The concept of the "dominant firm logic" refers to those governance structures that are used as the reference base for developing (national) laws, regulations and self-regulatory recommendations. ${ }^{9}$ Today, the dominant firm logic is highly based on AngloAmerican models - Berle and Means model - of the publicly listed company with a (very) dispersed shareholding. ${ }^{10}$ However, we argue that the prevailing global dominant firm logic is only relevant for certain types of firms. ${ }^{11}$ Optimal corporate governance can be developed along a double track: while the basic corporate governance principles are universal, their translation and implementation in practice need to be differentiated according to the type of firm (and its relevant governance challenges and problems). ${ }^{12}$

Van den Berghe et al. ${ }^{13}$ developed an enlarged reference framework for corporate governance integrating CSR. Six aspects are emphasized in the framework: managing conflicts of interest to prevent private benefits from prevailing over the corporate interest; redefining the role of the board in order to make the correct trade-offs; more effective monitoring through independent/objective directors; empowering the board to go beyond the pursuit of short-term shareholder value; no effective monitoring without information; responsible governance is not the duty only of business firms.

\footnotetext{
${ }^{6}$ Ibid.

${ }^{7}$ For more detailed information, see ibid and Van den Berghe et al. (2002).

${ }^{8}$ George (2001); Atkinson et al. (1997).

${ }^{9}$ Van den Berghe et al. (2002).

${ }^{10}$ Berle and Means (1932).

${ }^{11}$ Van den Berghe et al. (2002).

${ }^{12}$ For a more detailed analysis of the synchronization between firm typology and relevant corporate governance challenges, at the one hand, and corporate governance rules and recommendations, at the other hand, see Van den Berghe et al. (2002).

13 Ibid.
} 


\section{Relevance of corporate social responsibility and corporate governance for the insurance sector}

The financial and insurance sector is - as any other business sector - subject to tougher societal scrutiny although presenting a lower exposure to environmental risks. It has had its corporate scandals, especially in the 1980s and 1990s, including for example BCCI, Maxwell (pension fund) or Barings. These were certainly at the origin of a first wave of stricter corporate governance rules in the U.K. (like the Cadbury Code in the mid-1990). The more recent corporate collapses also had quite substantial indirect effects on the financial services sector. Some illustrative examples in this respect were the conflicts of interest of investment banks and financial analysts, or the loss of pension savings in the Enron case. Another recent example is the Marsh and McLennan case, the world's biggest insurance broker, on price fixing and collusion. Moreover, the insurance sector, which was heavily invested in stocks after the bull market of the 1990s, was greatly hurt by the stock exchange debacle that followed these corporate collapses.

The insurance sector presents some specific characteristics, which make it an interesting case for applying the analysis of CSR and corporate governance. In the following section, we will explore the positive and negative externalities of the insurance industry, its role as institutional investor and we will suggest some policy recommendations in order to mainstream modern concepts of CSR and corporate governance within the insurance industries.

\section{Sectoral relevance given its potential for specific positive externalities}

Given the huge potential for positive externalities, embedded in the insurance and financial services sector, it is clear that these firms perform a far greater role in society than their pure micro-economic market role. From a CSR perspective, this supposes that governments and civil society should foster the development of these sectors in order to optimize societal value. It is still open for discussion whether these positive elements are sufficiently taken into consideration or whether the potential for negative externalities has overwhelmed the public perception.

Management of pure risks: how financial institutions and insurers can help to solve societal problems

From a conceptual perspective, we have proven the positive externalities created by the insurance and financial services industry. ${ }^{14}$ In fact, by applying the law of large numbers, insurance companies transform individual insecurity into transferable risk and by doing so, they create a higher level of assurance and stimulate economic risk taking. Moreover, insurance is built on a solidarity mechanism between fortunate and unfortunate insured customers. In order to make insurance "affordable" to persons and organizations with higher risks, governments can even allow insurers to build in elements of obligatory systems of solidarity.

\footnotetext{
${ }^{14}$ Van den Berghe (1981).
} 
One of the ways CSR could translate into better performance at corporate as well as at societal level is through a more efficient and more effective risk management. The potential for positive externalities can clearly be documented by referring to some recent examples.

- Strict liability, especially for pollution, makes financial institutions and insurance companies directly or indirectly responsible for the projects they are insuring or financing. For example, in 1980, the Comprehensive Environmental Response Compensation and Liability Act (CERCLA) in the U.S. backed up the Environmental Protection Agency's (EPA) efforts to clean up contaminated sites. This Act - also known as Superfund - made owners of contaminated sites liable for the clean-ups. Although the Act exempted lenders from ownership status, due to the complexity of the issues involved, some banks were forced to enter into the court procedure and some recorded financial losses. ${ }^{15}$

- A second example is the Directive on Civil Liability for Damage Caused by Waste issued in 1989 by the European Commission. According to this document, the liability for damage caused by waste could be assigned to both a producer of the waste and a person "who had actual control of the waste, if he is not able within a reasonable period to identify the producer". ${ }^{16}$ The bankers' community found the wording "actual control" potentially dangerous, since the interpretation of the phrase could lead to lender's liability in certain instances.

- Another example is the Fleet Factors case in 1990. The Fleet Factors Corporation case was among the first in a series of legal proceedings in the U.S. that eviscerated the banks' exemption from Superfund liability. The liability issue has been an important element that started to question the role of financial institutions within sustainable development. Although it is a rather negative approach, financial institutions were forced to consider environmental aspects in their business.

The liability issue is certainly an imperative consideration to be taken up by financial institutions and insurers. They have an important role of assessing risks, estimating ways to manage these risks and calculate the return of possible risk management routes. The insurance industry can help to remediate environmental damage and provide a mechanism to internalize environmental and social externalities by putting a price on environmental and social risks.

Because it is desirable to prevent damage rather than remediate it, insurers need to send clear market signals to accurately price risks and reward socially and environmentally well-managed companies. Since reducing risk is in everybody's advantage and interest, it would be beneficial to the corporation as well as to society at large if CSR would result in risk reduction. This was shown in the European MultiStakeholder Forum by the case of Federchimica: after adopting their Responsible Care Programme, the number of accidents dropped significantly. This has a direct effect on the cost of insurance cover and hence, can be considered as a positive financial driver for CSR. On the other hand, if the business world is unable to answer

\footnotetext{
${ }^{15}$ Environmental Protection Agency (2001).

${ }^{16}$ Extracted from Schmidheiny and Zorraquin (1996).
} 
the societal needs, new liability legislation could be further forced upon them. To what extent this creates new captive markets for insurance cover will depend on the insurability of the risks involved.

Since liability has been clearly strengthened through legislation as well as through civil society, this also raises new challenges for corporate risk managers. If they want to gain access to bank finance or insurance at reasonable cost, they will need to improve their overall social and environmental performance.

Another relevant CSR issue for the insurance industry is climate change. Recent apparent instability in the weather and a succession of natural catastrophes have made it more difficult for insurers to calculate risks. The insurance industry already took some initiatives such as the development of financial tools to help business off-load some of its environmental risks, and the drafting by insurers of a U.N. charter on sustainable development. Leading insurers such as Munich Re and Swiss Re are taking the idea of global warming very seriously.

Management of business risks: how financial institutions and insurers can help to evaluate the governance and risk profile of the business firms

From a corporate governance perspective, the recent corporate collapses resulted in tougher regulations. Especially, the Sarbanes-Oxley Act (aiming at all multinational companies listed in the U.S.) directly and indirectly increased the focus on risk management for all companies worldwide. Directors, members of the audit committees as well as external auditors have to pay attention to the management of corporate risks, not just the financial or the insured ones. Directors are responsible for insuring that an effective system of risk management is installed. This results in the fact that the core business of insurers and financial service providers becomes all of a sudden one of the focal points of attention of boards and top management.

A positive side effect of the instrumental role insurance and financial services firms are playing could well be that they get more responsibility in judging the governance and risk profile of business firms. Regulations like Sarbanes-Oxley and the Basle II put indeed quite some additional responsibilities on the shoulders of insurers and bankers. The increased obligations on risk management and on monitoring of corporate governance required by Sarbanes-Oxley will necessitate that insurers take a closer look at these elements before accepting to take over some of the business risk.

- Illustrative in this respect are the problems encountered by AIG, which had insured the directors' liability of the failing Ahold executives. AIG blamed Ahold for their incorrect corporate governance. Recently, they finally reached an agreement that laid down some far tougher rules on the firm. Ahold put in place a series of measures that aim at reinforcing accountability, controls and corporate governance. They have replaced the decentralized system of internal control with a one-company system with central reporting lines. The Internal Audit department now not only reports to the Chief Executive Officer, but also to the Audit Committee of the Supervisory Board. The accounting and business control functions have become more centralized while the division of responsibilities at Corporate level is now better reflected through the establishment of separate Business Controlling and Accounting and Reporting departments. Ahold initiated a company-wide financial 
integrity programme, and is now convening a shareholders' meeting devoted solely to corporate governance. It is also one of the first companies in the Netherlands to implement the recommendation of the Dutch Tabaksblat Committee on corporate governance. Shareholders have been given more rights and the cumulative preferred financing shares have been restructured. All these proposals aim at improving transparency and a far-reaching increase in the power of Ahold's shareholders. Indeed, they are considered by third-party experts to be at the forefront of corporate governance initiatives in The Netherlands.

\section{Management of economic and system risks: the large-scale impact of financial intermediation}

By intermediating between surplus and deficit sectors, financial service providers create economic value while facilitating corporate and private financing as well as saving and investment. The less capital markets are developed, the more important this intermediation function becomes. In this respect, these firms can play a very important role in less-developed countries to start off economic development.

In buying insurance or investment products, trust in the service provider is of enormous importance. In life insurance and pensions, customers should have the trust that the company they pay yearly premiums to will still be around after 30 or 40 years and be able to pay them back all of their saving money. In entrusting one's money, savings or investments to financial service providers, a customer must have the necessary guarantees of solvency and liquidity at all times. Trust in the financial system is therefore of utmost importance for the stability of the economy, hence the serious interference of governments to regulate these activities.

\section{Special attention to the potential for negative externalities}

Unfortunately for the insurance and financial service providers, their sectoral specificities do not hold the potential only for positive externalities. On the contrary, important negative externalities can also occur. These have probably gained far more public attention (recently) than their positive side effects.

\section{The danger of false expectations and mis-selling}

Sometimes, customers of insurance and financial service providers suffer from illadvised products, overselling or even mis-selling. This has not only given rise to numerous customer complaints, but also to outright scandals. In some cases, it is clear that hard selling techniques and unfair distribution practices are at the heart of the problem. In other cases, it is more the complex nature of modern financial services that gives rise to the potential for miss-selling. The more developed capital markets become, the more financial products proliferate in all formats and shapes. These sophisticated products can pose complex challenges for advisors as well as for customers to choose the correct product that best fits the customers' specific needs. Moreover, the pricing of these products can become rather intransparent. This certainly holds for a great deal of investment products. That the potential for misselling is considerable has recently been shown in many countries: 
- Great negative publicity was given to the pension and mortgage mis-selling in the U.K.

- Another example of negative externalities was experienced by Dexia, a BelgianFrench financial conglomerate. They suffered a huge reputation loss as well as numerous court cases in relation to the stock-lease products developed by the investment company they bought from the Dutch insurer Aegon.

- In the U.S., numerous financial services providers have been condemned by the SEC for incorrect cost and investment allocations in their mutual funds in the U.S.

That the number of these complaints and court cases has drastically increased the last couple of years is probably not due, in the first place, to an enormous deterioration of the ethical stance of insurance and financial services firm. A far more important driver is to be found in the effects of the new invisible hand. The Internet lowered the barrier for product comparisons, while consumer groups and frustrated customers have made large-scale use of the media to echo their complaints publicly.

\section{The silent revolution in shifting the risk burden back to the customer}

Numerous examples of actual and future shifting of the risk burden back to the customer can be observed in the insurance world. This silent evolution could well become a boomerang if not well addressed and managed in a responsible way.

The more open the competition becomes and the more individualism reigns, the less viable is it to build large-scale solidarity into insurance products. In such environment, risk pricing becomes more and more individualized. For the good risks, this is a great evolution, but for the higher end of the risk spectrum, insurance cover becomes far more expensive if not outright unaffordable. This has been overwhelmingly clear in the tough competitive battle in markets like auto-insurance. In some countries, insurers have been blamed for reckless pricing on the back of the more problematic risk groups. This in itself is a proof of the externalities and their devastating potential effects on this type of business.

From a CSR perspective, a future time-bomb is ticking under the pension system. With the growing longevity, the funding of pensions is increasingly under attack. Governments, business firms as well as insurers and pension funds try to switch gradually from a defined-benefits to a defined-contribution system. The enormous impact of this shift is however not sufficiently explained and the potential risks involved, for the future generations of pensioners, are certainly not clear at all. In an era of increased accountability and scrutiny of the business world by civil society, it is in the interest of the service providers to invest more time and effort in improving the understanding of the great consequences of this shift. Another important step could be to offer sufficient transparency and choices, certainly for those that cannot or do not want to carry this risk burden themselves.

From dominant firm logic to fair value accounting: is there still a future for long-term risk spreading?

The focus on the dominant firm logic has driven the accounting principles into the direction of fair value accounting. In a listed company with dispersed shareholders, the 
market is finally the best monitor. However, market monitoring supposes very detailed disclosure, in order to make external monitoring feasible. Moreover, in a stock market where the engine is made up of sharetraders and daytraders, disclosure of fair market value is of tremendous importance. Although these recipes mainly hold for that dominant firm logic, as in any other field of corporate governance, all other types of firms are greatly affected too. In the EU, the IAS accounting regime will hold for all listed companies that have to publish consolidated annual accounts, including banks and insurance companies.

Without going into the detailed effects of this new accounting regime, it is necessary from the perspective of externalities to point to the negative effects this fair value accounting could have for the core business of insurance. Given the inversion of the exploitation cycle, the need for risk spreading from a time as well as from a customer perspective, insurers need to build substantial technical provisions. Such long-term stability buffers are essential for smoothly performing their core function. Indeed, insurance is embedded in uncertainties as to the timing, frequency and amounts of claims to be paid. This is in fundamental contrast with the short-term focus of fair value accounting. Although solutions can be found in the capital market to shift the burden away from insurers, it remains to be seen whether this shift is not endangering the mere existence of the insurance transfer function.

Specific corporate social responsibility and corporate governance relevance, given the role as institutional investor

Although to a different degree, all insurance companies, pension funds, investment funds, credit institutions, etc. perform a role as institutional investors. With respect to corporate governance as well as to CSR, the institutional investors can perform an important role.

\section{The potential role in shareholder engagement}

Many countries are supervising the investment behaviour of institutional investors in as far as it influences their solvency. Some go one step further, by making them accountable for effectively voting in shareholders' meetings. Even if accountable for voting behaviour, this mainly focuses on disciplinary mechanisms to improve shareholder return. However, institutional investors themselves are under increased scrutiny from society in two directions: they are increasingly questioned about their own corporate governance while pressure is also mounting to enlarge their accountability for checking also the CSR policies of firms. Indeed, insurance companies and pension funds are stewards of their customers' or members' money, and as such, they have a (very) powerful position. Their own corporate governance and CSR is increasingly being questioned:

... are these interventionist owners of shares, who may simply be stewards of pension fund investments, empowered to act in disregard of employee considerations?

... highly visible yet frequently anonymous, with notable exceptions, creators of mergers and acquisitions, financial engineers, asset strippers, institutions, whom 
I've already argued often, are but the stewards of pension fund investments masquerading as owners. ${ }^{17}$

As the recent literature points out, the interest of institutional investors in CSR is increasing. ${ }^{18}$ But also inter-governmental organizations such as the European Commission or the U.N. and governmental organizations are exerting pressures on financial institutions and insurance to engage in CSR through their powerful position as investors.

According to Clark and $\mathrm{Hebb}^{19}$ institutional investors changed behaviour in the 1990 s when they began to aggregate shareholders' interest and to use their concentrated power, and the resulting reductions in transaction costs, to actively engage with board of directors in order to lengthen investment horizons and raise firm-level standards of behaviour across a range of issues such as accountability, transparency and social and environmental standards. Shareholders have the right to align directors' interests with those of shareholders and hold them to account for the management and performance of the company. ${ }^{20}$

Institutional investors adopt different engagement strategies, which range from passive to active. The first strategy, negative screening, is based on exclusionary criteria through which investors make use of their exit voice. ${ }^{21}$ Basically, investors may decide to divest from a company or a whole sector if this one does not meet their criteria. The other strategies are positive screening, engagement and proxy voting. Hummels $e t \mathrm{al}^{22}$ define engagement as "influencing corporate policy by virtue of the position as investor and the associated rights". Shareholder activism is the strongest form of engagement where shareholders exercise their power through general protest voting at AGM or the support of socially responsible investment/corporate governance-related shareholder resolutions. ${ }^{23}$ Engagement differs from voting, as voting is often required by law and in that sense not necessarily an active stance. These strategies, especially the last two, are more active and involve the voice option. ${ }^{24}$ Rather than simply divesting from companies engaged in activities they consider to be contrary to their values, investors are choosing to actively invest and use their positions as shareholders to affect corporate behaviour. These strategies are not exclusive, and investors can apply combined strategies.

For a long time, the most active institutional shareholders have been found in the U.S., especially driven by large public pension funds like CalPERS and TIAA-CREF. More recently, the British insurers and pension funds started to develop their shareholder activism much more in concert with each other. Especially, sectoral organizations, like the Association of British Insurers (ABI) and their colleagues from

\footnotetext{
${ }^{17}$ Cassidy (2001).

${ }^{18}$ Hummels and Timmer (2003); Coles and Green (2002); Bayon (2001); Gribben and Faruk (2004).

${ }^{19}$ Clark and Hebb (2003).

${ }^{20}$ Forum for the Future (2002).

${ }^{21}$ See Hirschman (1970).

${ }^{22}$ Hummels et al. (2004).

${ }^{23}$ Eurosif (2003).

${ }^{24}$ See Hirschman (1970).
} 
the pension side, the National Association of Pension Funds (NAPF), played a prominent role in this respect. Now that they also joined forces with the Investment Management Association (IMA) and the Investment Trusts (ITs) to form the "Institutional Shareholders' Committee", they are really becoming a powerful monitor of business firms in the U.K.

Socially responsible investments: a marginal market or an important corporate social responsibility driver?

According to Insight Investment, institutional investors and fund managers have a responsibility towards stimulating CSR. They argue that socially responsible investment in particular might considerably influence the ethical stance of a company. As socially responsible investment receives growing attention, more companies are actively taking measures to make sure that they are not excluded from socially responsible investment indexes such as the FTSE4Good and the Dow Jones Sustainability Index. Therefore, socially responsible investment and investor relations' officers (who are both explaining companies' strategies to investors and echoing investors' expectations within their companies) are considered as possible drivers of a CSR approach for companies. However, it can take some years before investor relation officers will be able to perform their potential role as CSR catalysts.

Socially responsible investment is a growing phenomenon. Between 1984 and 2001, it grew from $\$ 40$ billion to $\$ 2.34$ trillion $^{25}$ in the U.S., and in Europe from 11.1 billion Euro in 1999 to 14.4 billion Euro in 2001. ${ }^{26}$ However, one should not overlook that socially responsible investment has still an extremely limited market share. Defining socially responsible investment funds from both a positive and negative screening perspective, the relevant socially responsible investment fund market is less than 1 per cent of the total retail market across Europe and between 2 and 3 per cent of the institutional market (figures for 2003).

Socially responsible investments: a need for evidence

According to Harry Hummels ${ }^{27}$ institutional investors will not consider socially responsible investment unless there is evidence that there is a positive link between social, environmental and ethical issues and long-term shareholder value.

Fiduciary duties are the most important duties of institutional investors. They are required to carry out investment decision in the sole interest of their beneficiaries. Since no law in Europe clearly and explicitly defines the relationship between fiduciary duty and social, environmental and ethical issues, institutional investors do not feel the necessity to integrate environmental and ethical issues in their investment policy. There are different views on this issue from both academics and practitioners. Generally, the traditional view considers socially responsible investment/corporate

\footnotetext{
${ }^{25} \operatorname{SIF}(2001)$.

${ }^{26}$ SIRI Group (2002).

${ }^{27}$ Interview with Harry Hummels, 25 May 2003
} 
governance as having a negative effect on the profitability and therefore may infringe upon their duties. Academic research, analysing the portfolio performance of socially responsible investment funds, shows diverse results. ${ }^{28}$ The dominant claim is that socially responsible investment provides higher financial returns than regular funds. ${ }^{29}$ A number of studies show inconclusive results either because of a lack of significant statistical difference between the returns of ethically screened and unscreened universes $^{30}$ or because of sector and style biases. ${ }^{31}$ Very few studies conclude that ethical funds under-perform. ${ }^{32}$

As long as the positive impact of environmental and ethical issues on portfolio performance is not shown, institutional investors will remain reticent to socially responsible investment. A positive relationship is a prerequisite for socially responsible investment to become a logical development. However, institutional investors are recognizing very slowly that social and environmental standards are appropriate concerns in order to ensure long-term returns and therefore fulfil rather than detract from their fiduciary duty.

\section{Linking socially responsible investments and corporate governance}

Recently corporate governance has become an important issue among institutional investors. The Parmalat and Enron scandals proved to the world that stakeholders can suffer from abuse by company management, as well as from misguided self-interest of influential shareholders. Moreover, research has shown that good corporate governance is positively linked to financial returns. Initially, the scientific research was directed mainly towards the relationship between one or more corporate governance characteristics and the share price, valuation and earnings or the company. Positive relationships were found. ${ }^{33}$ Other more comprehensive studies, such as Gompers et al., ${ }^{34}$ also showed positive results. Therefore and contrary to socially responsible investment, corporate governance does not face the question of fiduciary duties as described in the previous paragraph.

Although the Dutch Foundation for Corporate Governance Research for Pension Funds (SCGOP) recognizes only an indirect link between socially responsible investment and corporate governance, ${ }^{35}$ there are at least two clear links between the two (as we argued in the section The need for a new corporate governance paradigm and mechanisms). First of all, socially responsible investment and CSR advocate and encourage stakeholder dialogue. Shareholders are one of the stakeholders of the company and corporate governance enables the dialogue between the company and its shareholders through the right to information, shareholders' representation at company board level, the right to submit resolution at AGMs and

\footnotetext{
${ }^{28}$ See Louche (2004).

${ }^{29}$ Luther et al. (1992); Mallin et al. (1995); Snyder and Collins (1993); SIF (1998); Bauer et al. (2002).

${ }^{30}$ Diltz (1995); Sauer (1997).

${ }^{31}$ Louche (2001); Pava and Krausz (1996).

${ }^{32}$ Mueller (1991).

${ }^{33}$ Bauer and Gunster (2003); Millstein and MacAvoy (1998).

${ }^{34}$ Gompers et al. (2003).

${ }^{35}$ SCGOP (2004).
} 
voting rights. Secondly, good corporate governance, both in its informational and shareholders' rights aspects, enables socially responsible investment. As argued by Clark and Hebb, ${ }^{36}$ institutional investors have a role to play in the monitoring of firm management behaviour as they "engage directly with the firm through corporate governance over longer time periods" and "begin making linkages between the underlying fundamentals of the firm, its day-to-day decision-making process and longterm shareholder wealth". They also expect a greater awareness of the impact of corporate governance on long-term value after scandals such as Enron and WorldCom.

Through their rights, institutional investors can enable socially responsible investment and CSR. Indeed what we see developing lately is the broadening of shareholders' concerns, which increasingly include issues related to social and environmental concerns. They argue that a greater regard for long-term impacts of firms and increased CSR reduces risks adds share value and in the long term serves owners' interests. Although socially responsible investment and corporate governance have a different end, they can be seen as complementary. As Clark and Hebb ${ }^{37}$ said, there is an intersection of interest between the two.

Moreover, good corporate governance is central to engagement and voting. Although institutional investors may not use the traditional techniques of socially responsible investment, negative and positive screening, they may embrace corporate engagement and voting as a sound mechanism to raise firm-level standards and longterm performance. Through engagement, they will improve transparency and disclosure of companies.

Some suggestions for developing a policy for mainstream corporate social responsibility and corporate governance in the financial and insurance sector

\section{Greater emphasis on the management of negative externalities}

Compliance with customer needs Given the complexities involved with financial planning and risk management, an average customer is certainly not able to come up with a clear view on what his or her actual needs are and/or his or her future interests will be. With a more critical customer base and a more demanding society, the insurance and financial services sector can no longer allow itself to stick to a pushmarketing and a cross-selling attitude. The service providers need to invest more time and effort into a better understanding of the specific needs of the customer. In the context of the new invisible hand, too much focus on short-term profit at the cost of long-term sustainability can easily lead to a kind of a boomerang effect. Building a corporate culture that rewards integrity will probably be a far better instrument than any strict regulation.

Educative efforts towards (potential) customers Customers as well as employees and distribution representatives need a far better understanding of the complex characteristics of modern insurance and financial services products. Risk identifica-

\footnotetext{
${ }^{36}$ Clark and Hebb (2003).

${ }^{37}$ Ibid.
} 
tion, risk transfer and solidarity, investment options and cost elements all deserve far more attention. But the most difficult challenge will be to make the transfer from mere product information over financial education to good financial advice. Interesting in this respect is the recent initiative of the OECD, financed by Prudentia, to benchmark best practices in financial education (presented at the OECD Forum in Paris on 12 and 13 May 2004).

\section{Making more optimal use of the potential for positive externalities}

The focus of CSR and corporate governance on risk management carries huge potential for the insurance and financial services sector. This opens up new opportunities for the development of tailored business solutions. At the same time, trade federations and other sectoral organizations should more pro-actively build on the potential for improving the sector's reputation.

From a governance, as well as a CSR perspective, insurers, pension funds and other institutional investors will increasingly be placed before their responsibilities as "external" monitors of good corporate behaviour. The Combined Code on Corporate Governance has explicitly given the institutional investors the duty to perform a tough monitoring of the firms they invest in. After the Dutch Tabaksblat code did the same, there is now a Dutch initiative to install a special corporate governance commission to develop specific recommendations for the accountability of institutional investors. Faced with the potential for conflicts of interest, some of these service providers will turn to specialist shareholder services for outsourcing this important duty. However, with or without outsourcing, they will finally be held responsible for making full use of their potential for stimulating positive externalities also on this level.

In a recent speech at the London seminar of the International Insurance Society, the British Financial Services Authority explicitly stated their reliance on corporate governance mechanisms of insurers as a cornerstone for its regulatory approach.

\section{Conclusion}

From a societal perspective, the duties and responsibilities placed on the enterprise have increased drastically the last couple of years. The more the business world becomes a prominent economic force, the more society expects firms to operate in a responsible way. In essence, a responsible firm takes into consideration all direct and indirect external effects of its operation. By doing so, the business world "confirms" that the pure market theory as developed by neo-classicals and contractarians is incomplete in as far as they are ignoring these externalities.

As this paper shows, corporate governance and CSR are highly relevant for the financial and insurance sector. As any other sector of activity, financial institutions and insurers are subject to tougher societal scrutiny. Its specific core business, its environment and its important potential for positive and negative externalities make it an interesting sector for applying the analysis of CSR and corporate governance.

Financial institutions and especially insurers can play an important role as evaluators of risk management and estimating risk management returns as well as institutional investors. Transparency and CSR can become additional valued 
properties for the financial institutions and insurers. This is in line with the view of the World Business Council for Sustainable Development (WBCSD), which argues that the pursuit of sustainable development makes the organizations "[...]more resilient to shocks, nimble in a fast-changing world, [...], and more at ease with regulators". ${ }^{38}$ The increasing level of CSR with regard to investment strategy goes hand in hand with risk management and integration of CSR in organization structure. ${ }^{39}$ The investment policy must evolve hand in hand with risk management and must support the evolution of socially responsible investment and environmental, social and ethical considerations.

A full-fledged socially responsible investment strategy as investment strategy is maybe a too far-reaching approach. However, we believe that an engagement strategy may be a valuable strategy to stimulate CSR as it would provide financial institutions and insurers a direct contact with companies, including communication with senior management and board members about performance, corporate governance and other matters affecting shareholders' interests, including CSR. Insurance, as institutional investors, should use their voting rights. For this purpose, it would be useful to write a policy document on the exercising of proxy votes as well as communicate to the clients the voting activities in order to improve transparency.

The paper raised a number of issues that need to be further researched. First of all, financial services firms and insurance companies have to develop a better understanding of their numerous positive and negative externalities. However, assessment is only the first step in a comprehensive management of these externalities. Given the increasing attention on risk management and its relevance to both corporate governance and CSR, special focus must be given to build on the societal role the financial sector can play in this respect. In order to play its role of evaluator, the financial and insurance sector needs better tools to assess social and environmental risks. Moreover, corporate governance and socially responsible investment are two powerful means for CSR. Notwithstanding some integrative initiatives, they remain two separate concepts. Socially responsible investment rating organizations have recently tended to consider corporate governance more seriously and started to integrate some of these elements in their screening assessment. On the other end, corporate governance ratings only slowly started to integrate CSR-related indicators into their evaluation instruments. It would be of interest for both managers and academics to further investigate the link between corporate governance and socially responsible investment. It is only when there will be scientific certainty of a positive relationship that institutional investor may adopt a socially responsible investment strategy.

\section{References}

Atkinson, A.A., Waterhouse, J.H. and Wells, R.B. (1997) 'A stakeholder approach to strategic performance measurement', Sloan Management Review 38(3): 25-37.

Bauer, R. and Gunster, N. (2003) 'Goed bestuur loont voor beleggers', ESB also available at www.abp.nl.

\footnotetext{
${ }^{38}$ Holliday et al. (2002).

${ }^{39}$ Moskowitz (1972).
} 
Bauer, R., Koedijk, K. and Otten, R. (2002) 'International evidence on ethical mutual fund performance and investment style', Maastricht, Maastricht University and ABP Investments: 27.

Barrow, J.D. (1998) Impossibility, The Limits of Science and the Science of Limits, Oxford: Oxford University Press.

Bayon, R. (2001) 'Pension fund giant takes SRI flyer', Environmental Finance September 30.

Berle, A. and Means, G. (1932) The Modern Corporation \& Private Property, New York: McMillan.

Cassidy, D. (2001) Maximising Shareholder Value: The Risks to Employees, Customers and the Community, speech delivered at the Fourth International Conference on Corporate Governance and Direction Driving the Business Forward, Henley Management College.

Clark, G.L. and Hebb, T. (2003) Understanding pension fund corporate engagement in a global arena, working paper, School of Geography and the Environment, University of Oxford.

Coles, D. and Green, D. (2002) Do UK Pension Funds Invest Responsibly? A Survey of Current Practice on Socially Responsible Investment JustPensions.

Diltz, J.D. (1995) 'Does social screening affect portfolio performance?' Journal of Investing (Spring): 64-69.

Environmental Protection Agency (2001) 'Superfund', http://www.epa.gov/superfund.

Eurosif (2003) Socially Responsible Investment among European Institutional Investors, Eurosif (report).

Forum for the Future (2002) Sustainability Pays, Co-operative Insurance Society in association with Forum for the Future http://www.cis.co.uk/socacc2002/pdf/SusPays.pdf.

George, W.W. (2001) 'Medronic' s chairman William George on how mission-driven companies create longterm shareholder value', The Academy of Management Executive, Briarcliff Manor 15(4): 39-47.

Gompers, P.A., Ishii, J.L. and Metrick, A. (2003) 'Corporate governance and equity prices', The Quarterly Journal of Economics 118(1): 107-155.

Gribben, C. and Faruk, A. (2004) Will UK Pension Funds Become More Responsible? A Survey of Trustees (January), Just Pensions.

Hirschman, A.O. (1970) Exit, Voice, and Loyalty: Responses to Decline in Firms, Organizations, and States,, Cambridge: Harvard University Press.

Holliday, C.O., Schmidheiny, S. and Watts, P. (2002) Walking the Talk: The Business Case for Sustainable Development, Sheffield, UK: Greenleaf Publishing.

Hummels, H. and Timmer, D. (2003) Money and Morals, The Development of Socially Responsible Investing among Dutch Pension Funds, Nyenrode: Universiteit Nyenrode/VBA.

Hummels, H.J., Willeboordse, J. and Timmer, D. (2004) Corporate Shareholder Engagement: Investigating Corporate Governance and Sustainability in the Relation between Dutch Corporations and Their Investors, Nyenrode: Universiteit Nyenrode.

Huysse, L. (1999) De opmars van de calimero's. Over verantwoordelijkheid in de politiek, Van Halewyck, Leuven.

Louche, C. (2001) 'The corporate environmental performance-financial performance link', in J. Bouma, M. Jouchen and L. Klinkers (eds) Sustainable Banking - The Greening of Finance, Sheffield, UK: Greenleaf Publishing, pp. 187-200.

Louche, C. (2004) 'Ethical investment: processes and mechanisms of institutionalisation in the Netherlands, 1990-2002', PhD dissertation, Optima Grafische Communicatie, Erasmus University Rotterdam.

Luther, R.G., Matako, J. and Corner, D. (1992) 'The investment performance of UK ethical unit trusts', Accounting, Auditing and Accountability Journal 5(4): 57-70.

Mallin, C.A., Saadouni, B. and Briston, R.J. (1995) 'The financial performance of ethical investment funds', Journal of Business Finance and Accounting 22(4): 483-496.

Millstein, I.M. and MacAvoy, P.W. (1998) 'The active board of directors and performance or the large publicly traded corporation', Columbia Law Review 98(5): 483-496.

Moskowitz, M.R. (1972) 'Choosing socially responsible stocks', Business and Society Review 1: 71-75.

Mueller, S. (1991) 'The opportunity cost of discipleship: Ethical mutual funds and their returns', Sociological Analysis 52(1): 111-124.

Pava, M.L. and Krausz, J. (1996) 'The association between corporate social-responsibility and financial performance: The paradox of social cost', Journal of Business Ethics 15: 321-357.

Sauer, D.A. (1997) 'The impact of social-responsibility screens on investment performance: Evidence from the Domini 400 social index and Domini equity mutual fund', Review of Financial Economics 6(2): 137-149.

SCGOP (2004) Manual Corporate Governance. 
Schmidheiny, S. and Zorraquin, F. (1996) Financing Change: The Financial Community, Eco-efficiency, and Sustainable Development, London: MIT Press.

SIF (1998) Fund Performance. www.socialinvest.org.

SIF (2001) Report on Socially Responsible Investing - Trend in the United States, Social Investment Forum US.

SIRI Group (2002) Green, Social and Ethical Funds in Europe 2002, SiRi Group/Avanzi.

Snyder, J.V. and Collins, C.H. (1993) The Performance Impact of an Environmental Screen, Winslow Management Company.

Van den Berghe, L.A.A. (1981) Critical Analysis into the Validity of the National Accounting for the Evaluation of the Services Performed by the Insurance Sector, Etudes et Dossiers no 7, Geneva Association, p. 113.

Van den Berghe, L.A.A. and Baelden, T. (2003) 'Rebuilding trust: A challenge for corporate governance and audit', in L. Paape et al. (eds) Internal/Operational Auditing: bijdragen aan governance \& control, Amsterdam: NIVRA, pp. 291-307.

Van den Berghe, L.A.A. and Carchon, S. (2003) 'Redefining the role and content of corporate governance from the perspective of business in society and corporate social responsibility', in $\mathrm{P}$. Cornelius and $\mathrm{B}$. Kogut (eds) Corporate Governance and Capital Flows in a Global Economy, Oxford: Oxford University Press, Chapter 23.

Van den Berghe, L.A.A., Levrau, A. and Van der Elst, C. (2002) Corporate Governance in a Globalising World: Convergence or Divergence? A European Perspective, Dordrecht: Kluwer Academic Publishers.

Van den Berghe, L.A.A. and Verbeke, L. (2001) 'Duurzaam Ondernemen ... of het heruitvinden van de toekomst en het doorbreken van fundamentalismes', in H. Crijns and H. Ooghe (eds) De durf om te ondernemen: nieuwe aspecten van ondernemerschap en groeimanagement, Tielt: Lannoo Uitgeverij, pp. 224-235.

\section{About the Authors}

Lutgart Van den Berghe is professor at the University of Ghent (B) and the Vlerick Leuven Gent Management School. Her main topic of interest is "corporate governance" (including the role of Business in Society). In the school, she serves as an Executive Director and is Chairman of the Competence Center on "Entrepreneurship, Governance and Strategy". She is also Executive Director of the Belgian Directors' Institute and a Non-Executive Director in several international companies. Céline Louche is Senior Researcher at Vlerick Leuven Gent Management School at the Impulse Center Business in Society. Her research interest is CSR with a special focus on CSR and financial institutions. 